\title{
Knowledge and Practice about Use of Medication among Breast Feeding Women in Saudi Arabia: A Prospective Cohort Study
}

\author{
Sana Al Mahmoud ${ }^{1,2}$, Mohammad Daud Ali ${ }^{2}$, Ayaz Ahmad ${ }^{2, *}$ Alanood Al Maghrabi' ${ }^{2}$, Manal Al Harthi ${ }^{2}$, Nada Al Fattani ${ }^{2}$ \\ 'Department of Nursing Education, College of Nursing, Imam Abdulrahman Bin Faisal University, King Faisal Road, Dammam, SAUDI ARABIA. \\ 2Department of Pharmacy, Mohammad Al Mana College for Medical Sciences, Abdulrazaq Bin Hammam Street, As Safa, Dammam, SAUDI ARABIA.
}

\begin{abstract}
Background: Amount of drug in milk depend upon the concentration of drug in the mother's serum. Medications with more half-life time $\left(T_{1 / 2}\right)$ are likely to retain higher levels in breast milk. Also number of times of feeding and amount of milk taken by the infant are significant considerations. The main aim of this study was to evaluate the knowledge and practice about drug use while breastfeeding. Methods: A prospective cohort study was conducted and sample size was determined using Krejcie and Morgan's sample size calculator. A survey was carried in eastern province, Saudi Arabia community by approaching a conveniently selected sample of 545 participants. Results: The maximum percentage of participants were housewives $(43.11 \%)$ while the least participants were from health care professional $(6.97 \%, p<0.05)$. Among all the participants, maximum $(90.64 \%)$ were from urban residents Approx. $50 \%(p<0.05)$ of participants are not getting proper information from doctors about the prescribed
\end{abstract}

drugs. Conclusion: Awareness should be raised about the possible side effects of medication use during breastfeeding.

Key words: Breastfeeding, Knowledge, Practice, Eastern Provinces, Saudi Arabia.

Correspondence

Dr. Ayaz Ahmad,

Associate Professor, Department of Pharmacy, Mohammad Al Mana College for Medical Sciences, Abdulrazaq Bin Hammam Street, As Safa, Dammam-34222, SAUDI ARABIA.

Phone: +966 583486649

Email: 1980ayaz@gmail.com

DOI: 10.5330/ijpi.2019.1.5

\section{INTRODUCTION}

Administration of drugs to women who are breastfeeding may have ill effects on the suckling infant and/or affect lactation. Estrogens (in oral contraceptives) and bromocriptine (D2 agonist) decrease milk production. Pharmacologically significant amounts drug in milk is the cause of infant toxicity. Most of the drugs have low concentration in milk. But drugs acting on CNS and few others are mainly passing through milk and responsible for adverse effect in infant. Maternal medication or breastfeeding should not be interfered in case of such drugs. Though, currently available data are inadequate to make specific recommendations in the case of many drugs. Manufacturer's recommendations/package inserts should be consulted. ${ }^{1}$ Breast milk is compose of enzymes, nutrients, living nutritional fluid that contains hormones and antibodies. Breastfeeding has numerous advantages for offspring such as rarer infections, augmented intelligence, possible protection against overweight and diabetes and, for mothers, cancer protection. ${ }^{2}$ The World Health Organization (WHO) recommends mothers breastfeed entirely for 6 months post-delivery.

Drugs enter breast milk through passive diffusion of nonionized and non-protein-bound medication. Drugs with high molecular weights, lower lipid solubility and higher protein binding are less likely to pass into breast milk or transfer more slowly or in smaller amounts. The higher the serum concentration of drug in the mother's serum, the higher the concentration will be in the breast milk. Medications with longer halflife time $\left(\mathrm{T}_{1 / 2}\right)$ are further likely to retain higher levels in breast milk. The frequency and timing of feedings and amount of milk taken by the infant are significant considerations. Strategies for reducing risk to the infant from drug transferred through breast milk include selection of medications for the mother that would be considered safe for use in the infant; choosing medications with shorter half-lives; selecting those that are more protein bound, have lower bioavailability and have lower lipid solubility. ${ }^{3}$

\section{MATERIALS AND METHODS}

A survey was carried in eastern province, Saudi Arabia community by approaching a conveniently selected sample of 545 participants. A preliminary study has been piloted for testing validity of questionnaire response. A prospective cohort study was conducted for a duration of 3 months from January to March 2018, with the main aim to assess Knowledge and practice about use of medication amongst breast feeding women in Saudi Arabia.

\section{Ethical Approval}

Study has been approved by scientific research unit ethical committee of Mohammed Al Mana College for Medical Sciences, Saudi Arabia. Ethical approval number is $\mathrm{SR} / \mathrm{RP} / 08$.

\section{Sampling and sample size}

The sample size was determined using Krejcie and Morgan's sample size calculator. A confidence interval level 95\% with 5\% margin of error was used for statistical analysis. Though, by supposing a response rate of $80 \%$, a sample size of 480 was required for this study.

\section{Survey instrument}

A self-administered questionnaire was deliberate to gather the data from the contributors. All questionnaire is made by thorough study of intended after a systematic literature review. ${ }^{4-7}$ 
The survey consisted of two sections. The first section comprised of items related to demographic information of the contributors. Participants' replies were documented based on a 2-point Likert scale of agreement. The second section knowledge and attitude about use of medication among breast feeding women in Saudi Arabia.

\section{Data analysis}

The responses of the participants was analyzed by using SPSS v.20. Expressive analysis was used to express the demographic information in percentages and frequencies. Chi square test was used for calculation of $P$-value of different parameters.

\section{RESULTS}

\section{Demographic Characteristics}

The questionnaire were distributed to 649 subjects and among them 545 given the response with an overall response rate of $84 \%$. Most of the participants surveyed were Saudis. There were $488(89.54 \%, p<0.05)$ Saudis and $57(10.46 \%, p<0.05)$ Non Saudi. Study participants were within the age group from 17 to 50 years. As shown in Table 1, $1.6 \%$ of the subjects were from primary school, $19.44 \%$ from high school, $5.87 \%$ from secondary school followed by college degree holders (3.85\%), university students $(69.17 \%)$. The maximum percentage of participants were house wives $(43.11 \%)$ while the least participants were from health care professional $(6.97 \%, p<0.05)$. Among all the participants, maximum

\section{Table 1: Socio - Demographic Characteristics of Participants.}

\begin{tabular}{|c|c|c|}
\hline $\begin{array}{l}\text { Socio-demographic } \\
\text { Characteristics }\end{array}$ & $\mathbf{N}(\%)$ & P-Value \\
\hline \multicolumn{3}{|l|}{ Age ( Years ) } \\
\hline $17-20$ & $24(4.40)$ & \\
\hline $20-30$ & $131(24.03)$ & $p<0.05$ \\
\hline $30-40$ & $178(32.66)$ & \\
\hline $40-50$ & $212(38.89)$ & \\
\hline Nationality & & $p<0.05$ \\
\hline Saudi & $488(89.54)$ & \\
\hline Non-Saudi & $57(10.46)$ & \\
\hline Education & & $p<0.05$ \\
\hline Primary school & $9(1.6)$ & \\
\hline High school & $106(19.44)$ & \\
\hline Secondary & $32(5.87)$ & \\
\hline College & $21(3.85)$ & \\
\hline University & $377(69.17)$ & \\
\hline Occupation & & $p<0.05$ \\
\hline Student & $74(13.57)$ & \\
\hline Working & $198(36.33)$ & \\
\hline Health care professionals & $38(6.97)$ & \\
\hline House wife & $235(43.11)$ & \\
\hline Residence & & $p<0.05$ \\
\hline Rural & $42(7.70)$ & \\
\hline Urban & $494(90.64)$ & \\
\hline Suburban & $9(1.65)$ & \\
\hline Number of children & & $p<0.05$ \\
\hline Less than 3 & $221(40.56)$ & \\
\hline 3 & $70(12.84)$ & \\
\hline More than 3 & $254(46.60)$ & \\
\hline
\end{tabular}

${ }^{*} P$-value is considered statistically significant when it is $p<0.05$.
Table 2: Knowledge and attitude of participants about use of medication during breast feeding.

\begin{tabular}{|c|c|c|}
\hline Characteristics & $N(\%)$ & $P *$-value \\
\hline $\begin{array}{c}\text { Do you think it is safe to take medications while } \\
\text { breastfeeding? }\end{array}$ & & $p<0.05$ \\
\hline Yes & $50(9.17)$ & \\
\hline No & $453(83.11)$ & \\
\hline I don't know & $42(7.7)$ & \\
\hline $\begin{array}{l}\text { Have you taken any medication during } \\
\text { lactation? }\end{array}$ & & $p<0.05$ \\
\hline Yes & $228(52.84)$ & \\
\hline No & $317(58.16)$ & \\
\hline $\begin{array}{l}\text { If your answer is yes, have you Noticed any } \\
\text { changes in your child's behavior? }\end{array}$ & & $p<0.05$ \\
\hline Yes & $68(12.47)$ & \\
\hline No & $160(29.35)$ & \\
\hline $\begin{array}{l}\text { If you were prescribed a drug by a doctor during } \\
\text { lactation, did the doctor give you complete } \\
\text { information about the prescribed drugs? }\end{array}$ & & $p<0.05$ \\
\hline Yes & $276(50.64)$ & \\
\hline No & $79(14.49)$ & \\
\hline Sometimes & $190(34.86)$ & \\
\hline \multicolumn{3}{|l|}{$\begin{array}{c}\text { During dispensing did the pharmacist give you } \\
\text { complete information about the prescribed } \\
\text { drugs? }\end{array}$} \\
\hline Yes & $163(29.90)$ & $p>0.05$ \\
\hline No & $177(32.47)$ & \\
\hline Sometimes & $205(37.61)$ & \\
\hline $\begin{array}{l}\text { Have you taken a drug during lactation without } \\
\text { doctor prescription? }\end{array}$ & & $p<0.05$ \\
\hline Yes & $73(13.39)$ & \\
\hline No & $472(86.60)$ & \\
\hline \multirow[t]{2}{*}{$\begin{array}{c}\text { From where do you believe to get information } \\
\text { about safe use of medication for you and your } \\
\text { baby during breastfeeding? }\end{array}$} & & $p<0.05$ \\
\hline & $26(4.7)$ & \\
\hline Literature & $65(11.92)$ & \\
\hline Pharmacist & $343(62.93)$ & \\
\hline Physician & $12(2.20)$ & \\
\hline Social media & $58(10.64)$ & \\
\hline Web search & $41(7.52)$ & \\
\hline Other & & \\
\hline $\begin{array}{l}\text { In your opinion, is it better to take medications } \\
\text { before or after breastfeeding? }\end{array}$ & & $p<0.05$ \\
\hline Before Breastfeeding & $43(7.88)$ & \\
\hline After Breastfeeding & 304(55.77) & \\
\hline I don’t know & $198(36.33)$ & \\
\hline $\begin{array}{l}\text { Do you think natural remedies are safer than } \\
\text { modern drugs? }\end{array}$ & & $p<0.05$ \\
\hline Yes & $380(69.72)$ & \\
\hline No & $78(14.31)$ & \\
\hline Sometimes & $87(15.96)$ & \\
\hline $\begin{array}{l}\text { Do you suffer from any chronic illness? } \\
\text { (Diabetes, hypertension etc.) }\end{array}$ & & $p<0.05$ \\
\hline Yes & $101(18.53)$ & \\
\hline No & $444(81.46)$ & \\
\hline
\end{tabular}

${ }^{\star} P$-value is considered statistically significant when it is $p<0.05$. 
were from urban residents $(90.64 \%, p<0.05) .40 .56 \%$ participants were the mother of less than three children and $46.60 \%(p<0.05)$ participants were the mother of more than three children.

We observed that $9.17 \%$ mother belief that it is safe to take medications during breastfeeding while $83.11 \%(p<0.05)$ respondent's belief that it is not safe to take medications during breastfeeding (Table 2). Out of $52.84 \%$ of participants who are using medicine during breastfeeding, $12.47 \%$ mother observed that there is changing in child's behavior. $86.60 \%$ of participants are taking drug during lactation prescribed by doctor while only $13.39 \%(p<0.05)$ of participants have taken the drugs without prescription. Approx. $50 \%$ of participants are not getting proper information from doctors about the prescribed drugs and Approx. $70 \%$ $(p>0.05)$ of participants are not getting proper information from Pharmacist about the prescribed drugs (Figure 1). Although $62.93 \%$ and $11.92 \%(p<0.05)$ of participants believe to get information about safe use of medication from doctors and Pharmacist respectively (Figure 2). Approx. $70 \%$ of participants believe that natural remedies are safer than modern drugs. Among all the participants, $18.53 \%(p<0.05)$ are suffering from chronic illness like Diabetes, hypertension.

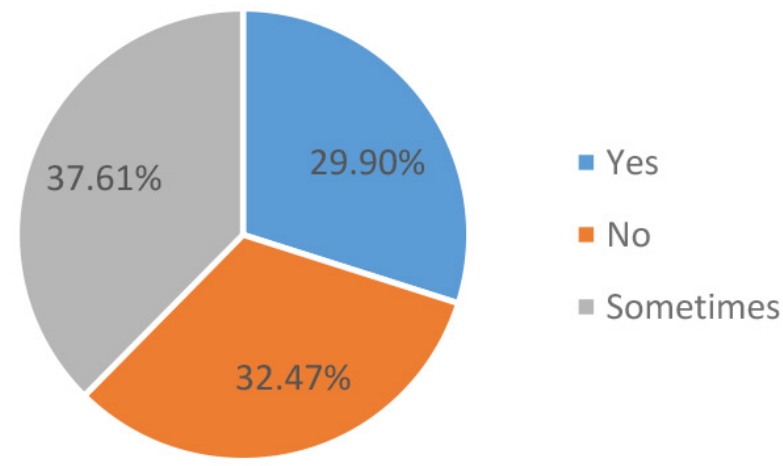

Figure 1: Complete information about the prescribed drugs given by pharmacist during dispensing.

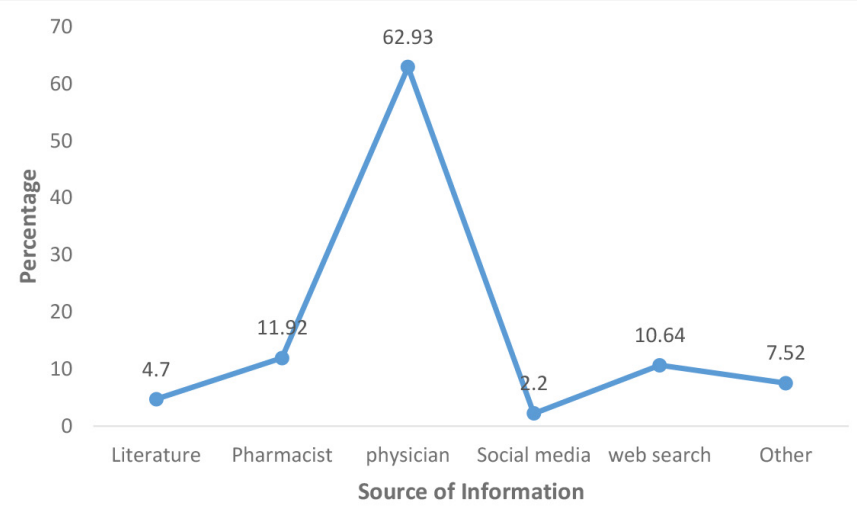

Figure 2: Source of information about safe use of medication during breastfeeding.

\section{DISCUSSION}

Most of the participants were university passed out (69.17\%), despite of that $13.39 \%$ of participants were taking drugs without prescription. For example, A survey was conducted by Nour A. Al-Sawalha, ${ }^{8}$ on breastfeeding women in hospitals and maternal and children care centers from each corner of Jordan by and found that $7 \%(n=64)$ used both over-thecounter and prescribed medications. A similar study was conducted in United States. ${ }^{9}$ and Participants were inquired to record the medications they had taken throughout breastfeeding and then were contacted every month throughout lactation and found that $96 \%$ of woman using medication while breastfeeding.

One of the main aims of this study was to estimate the degree of use of medication during breastfeeding. The results were alarming because $52.84 \%$ of women using medicine during breastfeeding and out of these, $12.47 \%$ mother observed that there is changing in child's behavior. In state hospital of Turkey, A descriptive study was conducted by Yalnizoglu Caka, ${ }^{10}$ on women who had breastfeeding for a period of the first 12 months, visited to outpatient clinic and found that $33.3 \%$ of participants said that they do not use any drug, despite of doctor's guidance to take drug, due to the distress of harm to the baby, while $75 \%$ believe not to use medication during breastfeeding.

It has been observed from this study, $83.11 \%$ respondent's belief that it is not safe to take medications during breastfeeding. Approx. $50 \%$ of participants are not getting proper information from doctors about the prescribed drugs and Approx. $70 \%$ of participants are not getting proper information from Pharmacist about the prescribed drugs. Despite of that $52.84 \%$ of participants are using medicine during breastfeeding.

\section{CONCLUSION}

Prior to beginning of drug treatment, breastfeeding women should be educated regarding the authentic sources of medication information and the significance of consultation to the physician. Pharmacists and Physicians should be stimulated to be enthusiastically involved in meticulous discussion with breastfeeding women regarding medication use.

\section{ACKNOWLEDGEMENT}

We would like to thank Dr. Aysha Almana, Mrs. Amal Kolghassi and Dr. Yousif Amin, MACHS, for supporting and making successful completion of this study.

\section{CONFLICT OF INTEREST}

All author(s) declare no conflict of interest.

\section{ABBREVIATIONS}

D2: Dopamine 2; CNS: Central Nerves system; WHO: World health Organization; SPSS: Statistical Package for the Social Sciences.

\section{REFERENCES}

1. Tripathi KD. Drugs in Breastfeeding. Essential of Medical pharmacology, seventh edition. Jaypee Brothers Medical Publishers (P) Ltd, India. 2013.

2. Victora CG, Bahl R, Barros AJ, França GV, Horton S, Krasevec J, et al. Lancet Breastfeeding Series Group. Lancet. 2016;387(10017):475-90.

3. Barbara GW, DiJoseph TP, Schwinghammer TL, DiPiro CV. Pregnancy and Lactation: Therapeutic Considerations, Pharmacotherapy Handbook and Seventh Edition. McGraw-Hill Companies. 2009;361-2,

4. Jackson KM, Nazar AM. Breastfeeding, the immune response and long-term health. J Am Osteopath Assoc. 2006;106(4):203-7.

5. Zhou Q, Li M, Wang X, Li Q, Wang T, Zhu Q, et al. Immune-related microRNAs are abundant in breast milk exosomes. Int J Biol Sci. 2012;8(1):118-23.

6. Wolf JB. Is breast really best. Risk and total motherhood in the national breast- 
feeding awareness campaign. J Health Polit Policy Law. 2007;32(4):595-636.

7. Jackson KM, Nazar AM. Breastfeeding, the immune response and long-term health. J Am Osteopath Assoc. 2006;106(4):203-7.

8. Al-Sawalha NA, Tahaineh L, Sawalha A, Almomani BA. Almomani. Medication Use in Breastfeeding Women: A National Study. Breastfeeding Medicine
2016;11(7):386-91

9. Esther ES, Jennifer LS, Michele LS, Ian MP, Cheston MB. Extent of Medication Use in Breastfeeding Women. Breastfeeding Medicine. 2007;2(3):145-51.

10. Yalnizoglu CS, Zengin $H$, Cinar NA. Drug use Knowledge and Practices of Mothers during Lactation Period. J Fam Med. 2016;3(4):1062.

Cite this article: Mahmoud SA, Ali MD, Ahmad A, Maghrabi AA, Harthi MA, Fattani NA. Knowledge and Practice about use of Medication among Breast Feeding Women in Saudi Arabia: A Prospective Cohort Study. Int. J. Pharm. Investigation. 2019;9(1):16-9. 